\title{
AN EVALUATION OF ACCESS TO UNIVERSAL BASIC EDUCATION IN SOKOTO STATE, NIGERIA
}

\section{Muhinat Bolanle Bello*, Dorcas Shola Daramola, Abdul Raheem Yusuf and Ismail Otekwu Amali}

Department of Social Sciences Education, Faculty of Education, University of Ilorin, Kwara State, Nigeria

*Corresponding author: muhinat4islam@yahoo.com

Published date: 10 August 2018

To cite this article: Bello, M. B., Daramola, D. S., Yusuf, A., \& Amali, I. O. (2017). An evaluation of access to universal basic education in Sokoto State, Nigeria. Asia Pacific Journal of Educators and Education, 32, 61-72. https://doi.org/10.21315/apjee2017.32.5

To link to this article: https://doi.org/10.21315/apjee2017.32.5

\begin{abstract}
Basic education is the bedrock upon which the secondary and higher education system is built in any nation's educational system because it is the foundation or first stage of formal education. Low enrollment of school age children in the country in general and northern part in particular has been worrisome to educationists, stakeholders and the federal government. The 1999 Universal Basic Education (UBE) was practical and pragmatic effort by the Government to address this problem. Sokoto State has been striving on the provision of UBE to its school age children over these years. Nonetheless, there is less academic focus on the evaluation of school age children access to UBE in the state. Therefore, this study evaluates access to UBE in the three senatorial districts of Sokoto State. Purposive sampling technique was adopted from the selection of the study sample. Specifically, the study evaluates the level of access of school age children to basic education in Kebbe, Wammako and Illelah local government areas of Sokoto State, Nigeria. Ex-post facto design was adopted for the study and profoma was designed to collect data from the school administrators and local education authorities. The study revealed that over $60 \%$ of school age children in Sokoto state were out of school, while only $33 \%$ were in school. It was recommended that there is the need for the Federal Government of Nigeria to plan or make available the type of education system (schooling system) that will suit the community of these school-age children.
\end{abstract}

Keywords: access, universal basic education, evaluation

(C) Penerbit Universiti Sains Malaysia, 2018. This work is licensed under the terms of the Creative Commons Attribution (CC BY) (http://creativecommons.org/licenses/by/4.0/). 


\section{INTRODUCTION}

This paper carried out an evaluation on the access to UBE programme at the basic Schools level in the three senatorial districts of Sokoto State, Nigeria. Education is a fundamental right of every child irrespective of whether the child is able or disabled (UNESCO, 2005). The child's socio-, economic background as well as gender should not be prerequisites for accessing basic education. Every child must be given the opportunity to learn to the extent of their ability so as to function effectively in the society where they live. Basic education is crucial to the self awareness which is an important requisite towards the agitation and enforcement of the fundamental right of an individual. Thus, basic education is important in attaining fundamental right of every citizen. Further, there are international human right instruments that provide for education as a fundamental human right at the UNESCO Convention against Discrimination in Education 1960, Social and Cultural Rights 1966, the African Charter on Human and Peoples' Rights 1986, the Convention on the Rights of the Child 1989, and A Human Rights-Based Approach to Education for All UNICEF/UNESCO 2007 (UNICEF \& UNESCO, 2007). These instruments accord all children access to free and compulsory basic education. Schooling brings about empowerment and increases productivity, thus, social vices such as child labour, and stealing are reduced in the society. This is why there has been a lot of emphasis most especially on access to basic education. Access to basic education has been upheld internationally and nationally. The World Conference on Education for All, Jomtein in 1990 and World Education Forum, The Dakar Framework for Action, EFA, 2000, and the Millennium Development Goals second sub-heading 2000; aims to achieve UBE by year 2015 all regard basic education as a necessity. Nigeria as a Country also aims at achieving the objectives of MDGs of which Basic education plays an essential role on the citizens' level of literacy in the Country.

\section{STATEMENT OF THE STUDY}

The Education for All (EFA) Assessment (UNESCO, 2000) shows that providing 'Education for All' is a realistic and achievable goal. However, progress has been reported to be uneven and far too slow as statistics show that of the more than 800 million children under six years of age, fewer than a third of the population benefit from any form of early childhood education. More pathetically, 113 million children, $60 \%$ of whom are girls, have no access to lower basic schooling and at least 880 million adults are illiterate, of whom the majority are women. These figures represent an affront to human dignity, a denial of the right to education and they stand as major barriers to eliminating poverty and attaining sustainable 
development. EFA Monitoring Team based on Nigeria report (UNESCO, 2010) revealed that an estimated 61 million children of primary school age do not have access to education globally with Nigeria having an estimate of 10.5 million outof-school children; in essence $17.21 \%$ of out-of-school children in the world are Nigerians. With the North-Western part of Nigeria constituting 9.5 million of this total (World Bank, 2012). World Bank (2013) reported Sokoto State amounting to $65.3 \%$ in 2011.

Sokoto State is one of the seven states in the North-Western region, which is the focal point of this study. The researchers were interested in Sokoto State because, the first attempt by the Federal Government of Nigeria to lunch Universal Free Primary Education (UPE) in 1976 was performed in Sokoto State. There was lowrate of enrolment among other challenges and there was the need for expansion when not much success was recorded. Statistics available shows that there was significant difference between the projected enrolment figure of school age children in the basic school and the actual figure after over 20 years of the implementation of Universal Free Primary Education (UNESCO, 1998).

This and many other factors prompted the federal government into expanding its scope of access through 'Education for All' programme which gave birth to the UBE. This is to allow school age children to access basic education free for the first nine years, and the programme UBE was re-lunched in Sokoto State in 1999 that was 23 years after UPE. However, the inevitable question is: How accessible has the programme been to school age children at the lower basic school level in the North-Western region especially Sokoto State? In other words, What is the level of access of children of school going age to basic education in the three senatorial districts of Sokoto State? The length and breadth of this paper provides answer to the extent of level of access of school age children to basic education in Sokoto State, Nigeria.

\section{REVIEW OF THE RELATED LITERATURE}

Formal education was introduced in Nigeria by Christian missionaries who arrived in the coastal area of the southern part in 1842 by the Methodist Missionary Society (MMS). However, According to Oni (2008), the universality of primary education in Nigeria dates back to the 1950s. In 1951, the Department of Education engaged in serious reflection on the educational policy of the whole country, there emerged Macpherson Constitution initiated by Sir John Macpherson the then Governor. In 1952, the Nation had three prominent political parties; National Council of Nigeria and the Cameroons (NCNC), Action Group (AG) and Northern People's 
Congress (NPC). These parties were popularly in control of government in the Eastern, Western and Northern Regions, respectively. Macpherson Constitution, among other things, made education a regional matter. Each of the three regions was henceforth, free to raise funds and enact laws on education. By July 1952, the Minister of Education in Western Region; S. O. Awokoya, presented a sessional paper on the educational policy of the region to the House of Assembly which was tagged "one of expansion and reorientation"; a policy for a six-year free primary education programme billed to start in 1955. From this target year, primary education in Western Region would be free and compulsory. Following this was the Eastern Region coming up with the Education Laws of 1956 and the Lagos Education Ordinance in 1957. Worthy of note is that the Regional Education Laws and Acts were derived from a common source, 'the Education Act 1944, of Wales and England (Imam, 2012). The Northern Region seemed to opt out of the race in the provision of free UPE. It appeared the region was so comfortable with the Islamic system of education which had been prevalent for centuries.

It was reported by Adesina and Ogunsaju (1982) that Nigeria had 15,703 primary schools with 2,912,600 pupils in attendance as at the time of her political independence in 1 October 1960. Four years after independence, the numbers went down to 14,976 with $2,849,500$ pupils in attendance. The UPE programme that originally started in the late 1950 s as a regional project was redesigned and launched by the military head of State- General Olusegun Obasanjo on Monday 6 September 1976, though, it was planned to be compulsory by 1979. Primary education was not only free but in addition universal in all the then nineteen states of the federation.

Admission into the six-year primary education programme was to be offered to six-year-olds and those who would be six years in the calendar year. The federal government budgeted N300 million for making structural and infrastructural facilities available in schools and another N200 million for the training of teachers. Two million, three hundred thousand $(2,300,000)$ children were projected to be enrolled in primary I. Projection of additional teaching staff and classrooms was put at 59,500 and 36,000, respectively (Oni, 2008). As asserted by Osokoya (1989), the decision to start Universal Primary Education and make it compulsory in 1979 was a clear demonstration of good intentions of the Government as well as in keeping up with the decision of the Addis-Ababa meeting of African Ministers of Education, 1961, which expressed the desire for African countries to achieve Universal Primary Education by 1980. 
Primary education remains the bedrock upon which the formal education system of any country of the world including Nigeria is built. Although the constitutional responsibility of basic education rests with the Local, State and Federal Governments. These three tiers of governments have been variously involved in the funding and management of basic education in Nigeria (UNESCO, 2000). Primary education is the stage patronized by a lot of learners because it is the foundation of the whole educational edifice. But, not all beneficiaries of primary education get to other levels. Acquisition of literacy and enlightenment which are the panacea for many problems including poverty, ignorance and so on are major benefits of primary education system.

The Educational sector (Universal Primary Education to be precise) like any other sector in Nigeria is bedeviled with many problems. Some of these were identified by Osokoya (1989) as inadequacy of teaching personnel, infrastructure, finance, and education imbalance in the country. The official teacher-pupil ratio should not exceed 1:30 or at most a maximum of 1:35 (UNESCO, 2000, Federal Republic of Nigeria, 2006). But, statistics from the Federal Ministry of Education shows that in 1994, there were 782 teachers and 18,296,202 pupils given teacher-pupils ratio of about 1:50 in 39,221 primary schools. On the contrary Olorunlero (2013) found out teacher-pupil ratio of 1: 15 and 1:16 in lower and upper basic schools in Kabba/Bunu LGA of Kogi State, Nigeria. As revealed by Odeleye, Oyelami and Odeleye (2012), an initiative in curbing some of the problems facing educational developments in Nigeria is the decentralization of educational administration and management.

In Nigeria, the trend has been that of the private sector gradually taking over the primary and secondary sub-sectors of the education industry. In most parts of South-West, South-East and South-South of the country, the number of privately owned pre-primary, primary and post-primary educational institutions have grown exceedingly and their enrolment figures have far exceeded enrolment in public schools and they also run the National Curriculum for basic education by Nigerian Education Research and Development Councils (NERDC) (Akpotu \& Akpochafo, 2009). It was revealed from Olorunlero (2013) study that private school have almost triple of the enrolment figures managed by the UBE schools. The concern about this finding is that parents prefer to enroll their children in private schools where they pay heavy school fees rather than enroll their children/wards in UBE schools for free? This is due to the fact that parents perceived that there is an educational standard in private schools compare to public schools. 
However, it is essential to glance through the goals and objectives of UBE in the National Policy on Education (Federal Republic of Nigeria, 2004):

1. inculcate permanent literacy and numeracy, and ability to communicate effectively;

2. lay a sound basis for scientific and reflective thinking;

3. give citizenship education as a basis for effective participation in and contribution to the life of the society;

4. mould the character and develop sound attitude and morals in the child;

5. develop in the child the ability to adapt to his changing environment;

6. give the child opportunities for developing manipulative skills that will enable him to function effectively in the society within the limits of his capacity; and

7. provide the child with basis tools for further educational advancement, including preparation for traders and crafts of the locality

The National Policy on Education (Federal Republic of Nigeria, 2004) further specified that the goals of Nigerian education are; to build a free and democratic society; just and egalitarian society; a united, strong and self reliant nation; a great and dynamic economy; and a land of bright and full opportunities for all citizens. As outlined in the first section, the philosophy espoused by this policy is to live in unity and harmony as one indivisible, indissoluble, democratic and sovereign nation; founded on the principles of freedom, equity and justice; and promote inter-Africa solidarity and world peace through understanding. The second and third sections of this policy gives a blueprint on early childhood/pre-lower basic schools education and basic education; stating that basic education shall be for a 9-year duration comprising of 6 years of Lower Basic Schools education and 3 years of Upper Basic Schools education which shall be free and made compulsory (Federal Republic of Nigeria, 2004).

From the forgoing, UBE can be regarded as an offshoot of the UPE in Nigeria and it is the strategy for the achievement of Education for All (EFA) and the education component of the Millennium Development Goals (MDGs). It is worthy to note that Nigeria is one of the 164 countries that signed the 2000 Dakar framework of Action to ensure 'Education for All' (EFA) by the year 2015. Alongside launching of the UBE programme is the enactment of the UBE Act in 2004. It provides for compulsory, free universal basic education for all school age children in the Federal Republic of Nigeria; stating clearly that "Education for all is the responsibility of all". It further seeks to provide punishment for parents for failing to comply 
with its provisions. In education, the term access typically refers to the ways in which educational institutions and policies ensure - or at least strive to ensurethat students have equal and equitable opportunities to take full advantage of their education Access to UBE is opportunity given to school age children to have basic education in terms of provision of basic schools and instruction to enable them acquire competence in literacy, numeracy and life skills. It could also be defined as the ability of all school aged children to have equal opportunity to education, regardless of their social class, gender, ethnicity background or physical and mental disabilities.

\section{OBJECTIVES}

The following are the objectives of UBE for the formal schooling years:

1. ensure unfettered access to nine (9) years of formal basic education. The provision of free, UBE for every Nigerian child of school going age;

2. reduce drastically the incidence of drop-out from the formal school system, through improved relevance, quality and efficiency;

3. ensure the acquisition of appropriate levels of literacy, numeracy, manipulative, communicative and life skills as well as the ethical, moral and civic values needed for laying a solid foundation for life-long learning;

4. develop in the entire citizenry, a strong conscientiousness for education and a strong commitment to its vigorous promotion; and

5. cater for young persons, their schooling as well as other out of school children or adolescent through appropriate form of complementary approaches to the provision of UBE.

In summary, Figure 1 illustrates the interrelatedness of the literature review in this paper.

\section{METHODOLOGY}

This study adopts ex-post facto design, this is a research design seeks to find relationship between independent and dependent variables after an action or event has already occurred (Salkind, 2010). All the UBE primary schools in Sokoto State constitute the population while three Local Government Areas in the three senatorial districts form the target population. A purposive sampling technique was adopted in the selection of three Local Government Areas. This is in line with Ujo 
(2000) who maintains that a researcher can purposively sample respondents for use if the researcher finds any attribute of interest in the population. These were Kebbe Local Government Area from Sokoto South Senatorial districts, Wammako Local Government Area from Sokoto North and Illela Local Government Area in Sokoto East senatorial districts of Sokoto State ( with no reference to the is private primary school) involved in the study. A researcher designed Proformawas used to obtained data on primary school enrolment into basic one (from 2004-2013). Gross intake rate was employed to evaluate the extent to which children have access to formal basic education, this was calculated using percentage.

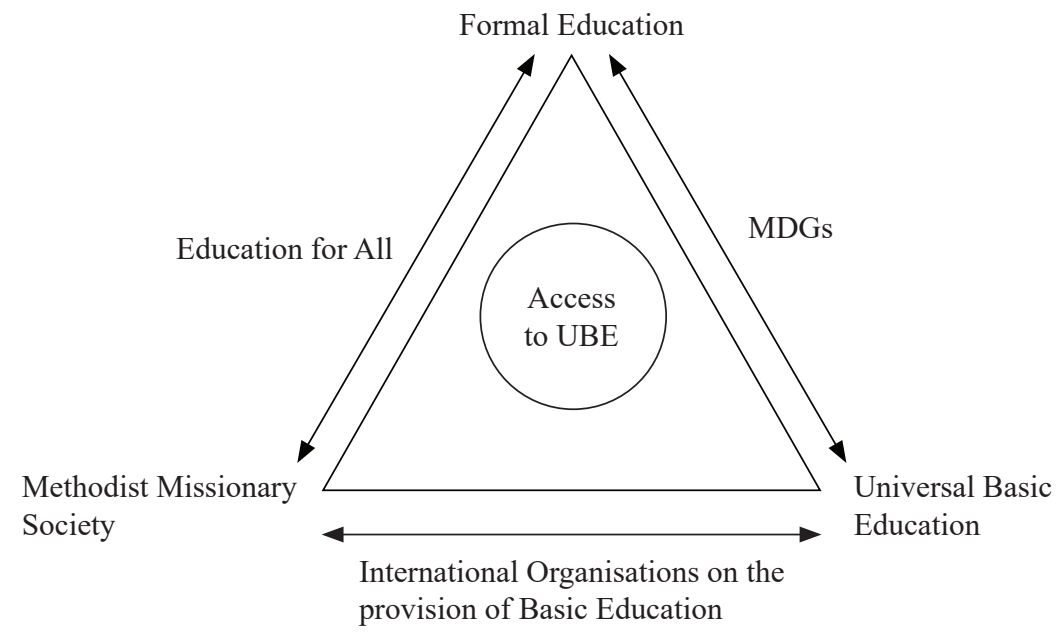

Figure 1. Inter-systemic scope for evaluating access to universal basic education in Sokoto State, Nigeria

\section{RESULTS}

As mentioned earlier that the main objective of this paper is to examine the level of access of children of school going age to basic education in the three Senatorial districts of Sokoto State.

To determine the degree of accessibility to primary education (lower basic education) total enrolment of school going age children admitted to government schools in Kebbe, Wammako and Illelah LGA's of Sokoto State was collected. This was expressed as a percentage of the population of the official school age children (Projected Population). This is called gross intake rate, because every child is expected to be in school, the gross intake rate is expected to be $100 \%$. 
Projected Population Figures were sourced from Sokoto State Ministry of Education (UBE schools).

Table 1 shows that the gross intake rate of children into primary one in Kebbe Local Government in Sokoto South Senatorial District were 54.4\%, 22.7\%, 28\%, 26\%, $44 \%, 30 \%, 27.4 \%, 33 \%, 36 \%$ and 33\%. In Illela Local Government of Sokoto East Senatorial District the gross intake rate into primary one were revealed as $18 \%, 20 \%, 36 \%, 75 \%, 37 \%, 25 \%, 25 \%, 31 \%, 27 \%$ and $30 \%$ while, the gross intake rate of children into primary one in Wammako Local Government in Sokoto North Senatorial District were 46\%, 50\%, 37\%, 31\%, 51\%, 62\%, 44\%, 41\%, 42\% and $43 \%$ for the years of study respectively. The findings also shows that the average Gross In-take Rate for 2004-2013 were 33.45\%, 32.4\% and $44.7 \%$ in Kebbe, Illela and Wammako respectively. This connotes that $66.55 \%, 67.6 \%$ and $55.33 \%$ of school age children are out of school in Kebbe, Illela and Wammako Local Government in Sokoto South Senatorial District.

\section{DISCUSSION OF FINDINGS}

Based on the data collected in this study, it was revealed that children above aged six are enrolled to basic education, and the level of access is below average because it was found out that more than $60 \%$ of school age children are out of school. This finding agreed with the submission of Olorunlero (2013) that access of children age 6-14years to basic education in Kabba/Bunnu Local Government Area of Kogi State is limited as over $30 \%$ of school age children are out of lower basic school (primary school) and over 20\% of children aged 6 to 14 are out of upper basic school. The finding also corroborate the report of EFA Monitoring Team Nigeria (UNESCO, 2010) which revealed that an estimated 61 million children of primary school age do not have access to education globally with Nigeria having an estimate of 10.5 million out-of-school children; in essence $17.21 \%$ of out-of-school children in the world are Nigerians. Similarly, the recent report by UNESCO EFA Global Monitoring 2013 (UNESCO, 2014) revealed that Nigeria is rated as having the highest number of children without access to basic education, despite an encouraging global figure that has fallen to 57 million. 
Table 1. Gross intake rate of children age Six into UBE in the LGA of Sokoto State (2004-2013)

\begin{tabular}{|c|c|c|c|c|c|}
\hline LGA & Years & $\begin{array}{l}\text { Total enrolment } \\
\text { to primary } 1 \\
\text { (UBE schools) }\end{array}$ & $\begin{array}{l}\text { Total enrolment } \\
\text { to primary } 1 \\
\text { (Private schools) }\end{array}$ & $\begin{array}{c}\text { Projected } \\
\text { population of } \\
\text { children age } 6\end{array}$ & $\begin{array}{l}\text { Gross intake } \\
\text { rate }\end{array}$ \\
\hline \multirow[t]{10}{*}{ Kebbe } & 2004 & 7,399 & - & 13,601 & $54.4 \%$ \\
\hline & 2005 & 4,211 & - & 18,490 & $22.7 \%$ \\
\hline & 2006 & 4,329 & - & 15,440 & $28 \%$ \\
\hline & 2007 & 5,212 & - & 19,922 & $26 \%$ \\
\hline & 2008 & 12,020 & - & 27,211 & $44 \%$ \\
\hline & 2009 & 8,991 & - & 29,980 & $30 \%$ \\
\hline & 2010 & 6,101 & - & 22,227 & $27.4 \%$ \\
\hline & 2011 & 5,623 & - & 17,001 & $33 \%$ \\
\hline & 2012 & 6,290 & - & 17,616 & $36 \%$ \\
\hline & 2013 & 5,241 & - & 15,788 & $33 \%$ \\
\hline \multirow[t]{10}{*}{ Illela } & 2004 & 4,010 & - & 22,511 & $18 \%$ \\
\hline & 2005 & 3,301 & - & 16,661 & $20 \%$ \\
\hline & 2006 & 6,540 & - & 18,090 & $36 \%$ \\
\hline & 2007 & 9,300 & - & 12,391 & $75 \%$ \\
\hline & 2008 & 10,101 & - & 27,210 & $37 \%$ \\
\hline & 2009 & 7,430 & - & 30,287 & $25 \%$ \\
\hline & 2010 & 5,112 & - & 23,916 & $25 \%$ \\
\hline & 2011 & 6,212 & - & 20,217 & $31 \%$ \\
\hline & 2012 & 10,131 & - & 37,138 & $27 \%$ \\
\hline & 2013 & 12,320 & - & 40,878 & $30 \%$ \\
\hline \multirow[t]{10}{*}{ Wammako } & 2004 & 13,220 & - & 28,909 & $46 \%$ \\
\hline & 2005 & 11,521 & - & 23,009 & $50 \%$ \\
\hline & 2006 & 6,018 & - & 16,119 & $37 \%$ \\
\hline & 2007 & 5,307 & - & 17,244 & $31 \%$ \\
\hline & 2008 & 9,741 & - & 19,099 & $51 \%$ \\
\hline & 2009 & 9,091 & - & 13,792 & $62 \%$ \\
\hline & 2010 & 11,770 & - & 27,044 & $44 \%$ \\
\hline & 2011 & 15,816 & - & 38,183 & $41 \%$ \\
\hline & 2012 & 3,657 & - & 8,748 & $42 \%$ \\
\hline & 2013 & 9,011 & - & 20,835 & $43 \%$ \\
\hline
\end{tabular}

\section{CONCLUSION AND RECOMMENDATIONS}

One can therefore conclude based on the findings of this study that the level of access of school going age children to Lower Basic Education which is the gateway to formal education in Sokoto State is very low. This is visible in the increase in the numbers of Almajiri children on the street. Therefore, constituting threat to the realization of the goals and objectives of Education for All, Millennium 
Development Goals and Nigeria vision of the becoming one of the most 20 developed Nations of the World (vision 20:2020).

On these bases, the study recommended that, there is the need for the Federal Government of Nigeria to plan or make available the type of education system (schooling system) that will suit the community of these school-age children. Example of such type of schooling system is shift classes: afternoon or evening classes. This could enable school to double its effort without necessarily increase infrastructure to provide access to school-age children. Also access to school can be created through non-formal school programme. The programme will help to expand access to quality, protective and relevant alternative educational opportunities for out-of-school child. Lastly, flexibility of existing school hours and system.

\section{REFERENCES}

Adesina, S. \& Ogunsaju, S. (Eds.). (1982). Primary education in Nigeria. Ibadan: Board Publications Limited.

Akpotu, N. E., \& Akpochafo W. P. (2009). An analysis of factors influencing the upsurge of private universities in Nigeria. Kamla-Raj Journal, 18(1), 21-27. https://doi.org/10.1080/09718923.2009.11892663

Federal Ministry of Education. (1999). Education for all 2000 assessment: Country report of Nigeria (Under the coordination with MOA Olorufunmi). Abuja, Nigeria: Author.

Federal Ministry of Education (2008). Teacher's handbook on the new basic education curriculum. lower basic schools school level. Lagos: NERDC Printing Press.

Federal Republic of Nigeria (2004). Nigeria National Policy on Education. Abuja. Nigeria: Nigerian Educational Research and Development Council (NERDC).

Federal Republic of Nigeria (2006). National Policy on Education. Abuja. Nigeria: Nigerian Educational Research and Development Council (NERDC).

Imam, H. (2012). Educational policies in Nigeria from the Colonial era to the postindependence period. Italian Journal of Sociology of Education, 4(1), 181-204.

Odeleye, D. A., Oyelami, O., \& Odeleye, A. (2012). Private ownership and educational management in Nigeria: Issues and challenges. JORIND 10(2), 23-24.

Olorunlero, J. I. (2013). Evaluation of access to Universal Basic Education in Kabbal Bunnu Local Government Area of Kogi State, Nigeria. Unpublished Masters thesis, University of Ilorin, Ilorin.

Oni, J. O. (2008). Universality of primary education in Nigeria: Trends and issues. International Journal of African \& African American Studies. 8(1), 23-31.

Oni, J. O. (2009). Management of lower basic schools education in Nigeria: Trends, constraints and solutions. Madwell Journals: Social Sciences, 4(3), 286-290.

Osokoya, I. O. (1989). History and policy of Nigerian education in world perspective. Ibadan: AMD Publishers. 
Sambo, A. A. (2008). Research methods in education. Edo: Stirling-Horden Publishers.

Salkind, N. J. (2010). Encyclopedia of research design. Thousand Oaks, CA: SAGE Publication.

Ujo, A. A. (2000). Social research: A non- quantitative approach. Nigeria: Anyaotu Enterprise and Publisher Ltd.

United Nations Educational, Scientific and Cultural Organization (UNESCO). (1998). UNESCO report: Is the world on track? Retrieved from http:/www.unicef.org/ earlychildhood/index_integratedapproach.html

UNESCO. (2000). The state of education in Nigeria. Abuja: UNESCO.

UNESCO. (2005). Education for all: A report of the expert panel on literacy and numeracy for students with special education needs, kindergarten to grade six. Retrieved from http://www.oafccd.com/documents/educationforall.pdf

UNESCO. (2007). UNESCO operational definition of basic education: Thematic framework (December 2007). Retrieved from http://www.unesco.org/education/ framework.pdf

UNESCO. (2010). EFA Global monitoring report: Educational models for life and work. Retrieved 16 November 2012 from http://www.unesco.org/uil/litbase/? menu $=9$ \&programme $=39$

UNESCO. (2014). EFA Global monitoring report 2013/2014: Teaching and learning: Achieving quality for all. Retrieved from http://unesdoc.unesco.org/ images/0022/002256/225654e.pdf

United Nations Children's Fund (UNICEF), \& UNESCO. (2007). A human rights-based approach to education for all: A framework for the realization of children's right to education and rights within education. New York: UNESCO. Retrieved from https://www.unicef.org/publications/files/A_Human_Rights_Based_Approach_ to_Education_for_All.pdf

World Bank. (2012). World Development Indicators. Retrieved from http://data.worldbank. org/indicator/SI.POV .DDAY

World Bank (2013). Nigeria education and skills policy notes: Policy note 1 - access, equity and quality in Nigeria (Unpublished). World Bank. 